\title{
APLIKASI SISTEM MONITORING KUALITAS AIR DANAU SEBAGAI MITIGASI KEBENCANAAN BERBASIS IOT
}

\author{
Dirvi Eko Juliando Sudirman ${ }^{1)}$ dan Nur Asik Hidayatullah ${ }^{2)}$ \\ ${ }^{1}$ Teknik Komputer Kontrol,Politeknik Negeri Madiun, Jalan Serayu no 84, Madiun, 63133 \\ ${ }^{2}$ Teknik Listrik, Politeknik Negeri Madiun, Jalan Serayu no 84, Madiun, 63133 \\ E-mail: ${ }^{1}$ dirvi@pnm.ac.id
}

\begin{abstract}
The mass death of fish in a lake or a fish pond sometime occurs due to unmonitored its water quality. This problem leads to farmer's profit losses that can not be avoided. Therefore, to overcome the problem it requires an applied system that able to monitor fish pond water quality. This paper proposes an application for monitoring lake or fish pond water quality based on acidity(PH), turbidity, dissolved oxygen (DO) and water temperature parameters. The main objectives is to provide early warning when the fish pond's water quality is close to the threshold of danger. Thus the mass death of fish can be avoided and minimized. In addition, the water quality data measured by the sensor will be collected in the data logger and be forwarded to the data using the cellular network. All the submitted data will be stored and displayed on the website enable to be accessed from anywhere and can be used by interested parties.
\end{abstract}

Keywords: Monitoring, Quality, Lake,Mitigation, Disaster, IOT

\begin{abstract}
ABSTRAK
Kematian masal ikan yang hidup disuatu danau kadang terjadi akibat terlambatnya atau tidak termonitoringnya kualitas air di danau tersebut, sehingga kerugian yang dialami oleh peternak tidak dapat dihindari. Untuk itu sistem ini diaplikasikanuntuk monitoring kualitas air danau berdasarkan parameter kadar keasaman (PH), kekeruhan, oksigen terlarut (DO) dan suhu air.Sistem ini bertujuan untuk memberikan peringatan dini ketika kualitas air danau sudah mendekati ambang batas bahaya sehingga kerugian penambak ikan didanau tersebut dapat diminimalisir. Selain itu data kualitas air yang diukur oleh sensor akan dikumpulan di data logger yang kemudian akan diteruskan ke pusata data menggunakan jaringan selular. Data yang dikirimkan akan disimpan dan ditampilkan di website sehingga dapat diakses dari manapun dan dapat digunakan oleh pihak-pihak yang berkepentingan.
\end{abstract}

Kata Kunci: Monitoring, Kualitas, Danau, Mitigasi, Kebencanaan, IOT

\section{PENDAHULUAN}

Kompas, medan 13 januari 2017 "Paling tidak 249,6 ton ikan di keramba jaring apung di Danau Toba yang berada di Desa Tipang dan Simangulampe, Kecamatan Baktiraja, Kabupaten Humbang Hasundutan, Sumatera Utara, mati selama enam hari terakhir. Jumlah itu belum termasuk kematian ikan liar di Desa Tipang, Simangulampe, Sinambela, dan Marbuntoruan. Kasus ini merupakan kasus kematian massal ikan kelima yang terjadi di sejumlah tempat di sekeliling Danau Toba setahun terakhir.
Selain di Baktiraja, kematian massal ikan juga terjadi di Desa Haranggaol, Kecamatan Haranggaol Horison, Simalungun; Desa Tongging, Kecamatan Merek, Karo; Desa Silalahi dan Desa Paropo, Kecamatan Silalahi Sabangun, Dairi; dan Desa Tanjung Bunga, Kecamatan Pangururan, Samosir. Rudy mengatakan, total kerugian petani sekitar Rp 6 miliar”. Gosumbar.com Agam - "Berdasarkan dari data Dinas Kelautan dan Perikanan (DKP) Kabupaten Agam, Sumatera Barat, kerugian petani atau petambak keramba jaring apung di Danau Maninjau mencapai Rp39.254.000.000, akibat ikan mati secara (Misterius) 
mendadak, semenjak Januari sampai September 2016”. Di Indonesia berlum terdapatnya sistem untuk memonitoring kualitas air danau secara real time. Hal ini dapat diatasi dengan menggunakan manajemen kualitas air. Tujuan dari manajemen kualitas air adalah memastikan keterbelanjutan sumber air untuk masa depan. Manajemen sumber daya air tidak hanya masalah tentang konservasi air tetapi juga termasuk memberikan informasi tentang kualitas air, yang harus dapat diakses oleh publik sehingga persiapan awal dapat diambil oleh mereka yang terkena dampak degradasi dalam kondisi air (D. Hou.2013). Hal ini juga bertujuan untuk memantau kualitas sumber air yang digunakan untuk minum (D. D. Ediriweera, 2010) juga untuk memantau kondisi air tanah (Y. Zhang,, 2014)

Untuk mengatasi masalah tersebut dapat diterapkan teknologi WSN dalam memantau kualitas air dengan menggunakan pendekatan pengumpulan, transmisi dan pengolahan data secara online (M. Shell.2002). Perkembangan teknologi deteksi yang murah, akurat dan memiliki daya jangkau yang lebih luas diwujudkan dalam sebuah bentuk jaringan sensor (network-ed sensor). Jaringan sensor itu sendiri berbentuk satu kesatuan dari proses pengukuran, komputasi, dan komunikasi yang memberikan kemampuan administratif kepada sebuah perangkat, observasi, dan melakukan penanganan terhadap setiap kejadian dan fenomena yang terjadi di lingkungan. Dalam kondisi seperti itu tidak dimungkinkan komunikasi menggunakan kabel, perlu adanya suatu jaringan tanpa kabel untuk nantinya menguatkan paket data yang bertujuan menyampaikan data informasi dari single node. Dengan teknik ini dimungkinkan area yang terjangkau pada komunikasi itu lebih luas (A.Gaddam, 2014). Hal ini diterapkan pada jaringan sensor nirkabel atau wireless sensor network.

Kelebihan utama dari WSN adalah murah dalam penerapan dan perawatan, karena tidak memerlukan insfrastruktur yang tetap, penggunaan daya yang rendah dan dapat dipindah sesuai daerah yang ingin diamati (A.Faustine.2014). Perkembangan arsitektur dari wsn mengarah pada system pencatatan tertentu dalam mengambil data dari lingkungan sekitarnya dan mengirimkan ke server data, dimana akan disebarkan luaskan melalui halaman web atau perangkat ponsel (D. Sirisha,2015). Sistem monitoring kualitas air danau berbasis IOT dirancang dan diimplementasikan di telaga Ngebel Ponorogo Jawa timur. Telaga Ngebel dipilih dikarenakan telaga Ngebel selain digunakan untuk wisata air juga terdapat banyak kerambah-kerambah milik peternak ikan, selain itu juga telaga Ngebel dekat dengan sumber air panas yang mengandung banyak belerang. Sehingga faktor tercemarnya air telaga Ngebel oleh unsur belerang sangat besar kemungkinannya, dimana pencemaran ini dapat menyebabkan kematian masal ikan-ikan yang ada ditelanga Ngebel.

\section{METODE PENELITIAN}

Salah satu kelebihan dari sistem ini adalah, sistem dibuat berbasis modular untuk mempermudah perawatan dan modifikasi. Sistem terdiri dari modul sensor-sensor, data loger, transmitter dan web server. Data dari kualitas air disekitar buoy dikumpulkan menggunakan moduler sensor-sensor. Data-data kualiatas air yang telah dikumpulkan oleh sensoro akan disimpan di data loger sementara yang ada di buoy, yang kemudian akan ditransmit ke web server dengan menggunakan protocol GPRS/GSM. 


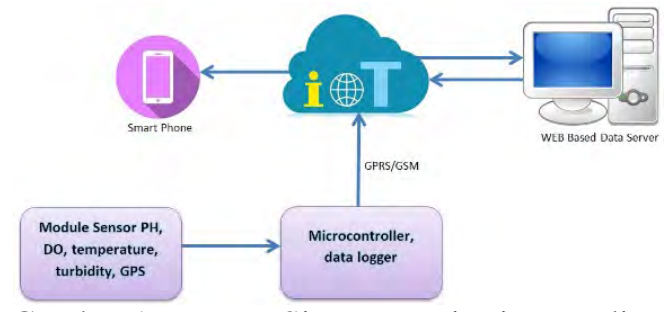

Gambar 1. Konsep Sistem Monitoring Kualitas Air Danau (Sumber: Rancangan dari sistem, 2018)

Ada beberapa fitur tambahan yang terdapat disistem ini, antara lain pengambilan data kualitas air oleh sensor dilakukan per 10 menit yang kemudian akan ditampung sementara di data logger yang terdapat di buoy. Data yang tersimpan di data loger akan segera dikirimkan ke web server, ketika data yang ada di datalogger berhasil dikirim maka sistem akan segera mereset dan menghapus data yang terdapat di dataloger. Hal ini dilakukan dengan tujuan tidak memerlukan data longger yang mempunyai kapasitas besar, sedangkan keseluruhan data akan disimpan di web server dan dapat diakses melalui halaman web. Konsep dasar dari sistem monitoring kualitas air danau berbasis IOT ditunjukan pada gambar 1.

Modul sensor digunakan untuk mengambil data-data kualitas air ditelanga Ngebel. Modul sensor terdiri dari modul sensor $\mathrm{PH}$, modul sensor DO (kadar oksigen terlarut), modul sensor suhu, modul sensor kekeruhan air. Mikrokontroler digunakan untuk mengambil data dari modul-modul sensor.

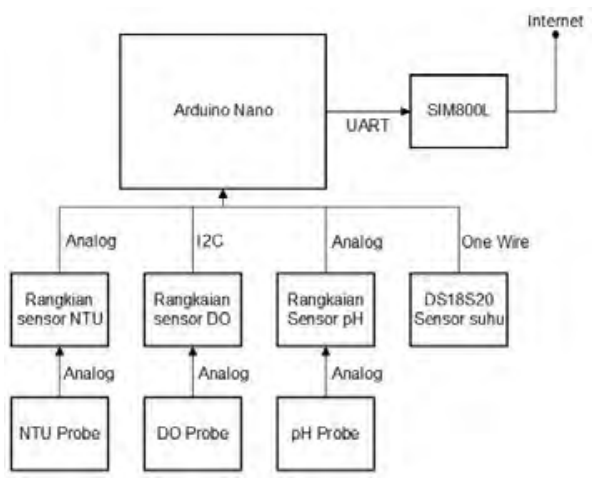

Gambar 2. Blok Diagram Modul Sensor (Sumber: Rancangan dari sistem, 2018)
Mikrokontroler juga berperan untuk menyimpan data sementara sebelum di kirim ke web server. Proses transmisi data dari mikrokontroler ke web server menggunakan protocol GSM/GPRS. Sedangkan komunikasi antara mikrokontroler ke GSM/GPRS modul menggunakan komunikasi serial UART. Flowchart dari sistem monitoring dan diagram blok dari modul sensor dapat dilihat pada gambar 2 dan gambar 3 .

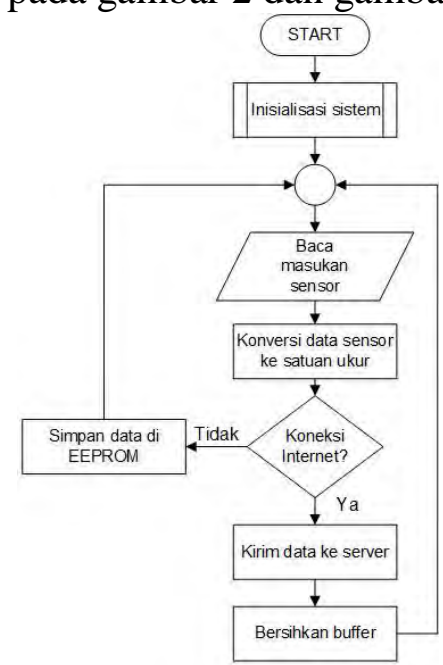

Gambar 3. Flowchart Sistem Monitoring (Sumber: Rancangan dari sistem, 2018)

Data logger digunakan untuk menyimpan data yang diperoleh dari sensor sebelum dikirim ke data base. Selain itu data logger juga berperan sebagai backup ketika sistem monitoring tidak dapat terhubung dengan data base. Transmisi data dari sistem ke web server tidak selamanya berjalan dengan baik. Ada kemungkinan dikarenakan faktor cuaca atau faktor perawatan dan juga gangguan yang dialami oleh penyedia layanan internet sehingga data tidak dapat terkirim ke web server. Ketika sistem tidak dilengkapi oleh data logger maka ketika terjadi gangguan maka dan data hasil monitoring kualitas air danau tidak dapat terkirim maka data tersebut akan hilang akibat tergantikan oleh data dari pengambilan selanjutnya. Ketika hal ini terjadi maka akan terdapatnya beberapa hasil monitoring yang kosong pada saatsaat tertentu. Untuk mengatasi kelemahan tersebut diperlukan data 
logger. Pada sistem ini data logger dirancang dengan kapasitas sebesar 40Kb. Kapasitas ini dianggap cukup mumpuni untuk menyimpan data-data hasil monitoring dari sensor. Sedangkan besar data dari masing-masing sensor sebesar 4 byte, sehingga berdasarkan hal tersebut maka data logger mampu menyimpan data hasil monitoring yang dilakukan selama 41 jam berturut-turut. Selain itu, pada sistem ini data logger dirancang dimana ketika mikro dapat terhubung dengan internet dan dapat mengirimkan data yang tersimpan di data logger maka mikro akan segera menghapus data-data yang telah terkirimkan tadi. Sehingga tidak akan terjadinya kasus dimana data logger mengalami kelebihan kapasitas. Flowchart dari data logger diperlihatkan pada gambar 4 .

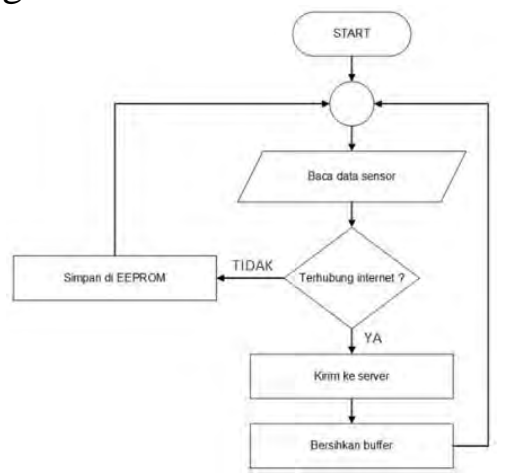

Gambar 4. Flowchart sistem data logger

(Sumber: Rancangan dari sistem, 2018 )

Solar cell digunakan sebagai penghasil daya listrik yang dibutuhkan oleh sistem. Perangkat keras dari monitoring kualitas air danau yang diletakkan di buoy terdiri dari 4 buah modul sensor, satu buah mikrokontroler dan satu buah GSM/GPRS modul. Perangkat keras tersebut mengkonsumsi 500mWh. Untuk memenuhi kebutuhan energy tersebut, sistem menggunakan baterai sebagai pemasok daya. Untuk mengisi ulang energi baterai yang habis dikonsumsi oleh perangkat keras sistem digunakan sel surya. Pada siang hari sel surya akan digunakan untuk mengisi kembali baterai yang digunakan, sekaligus digunakan untuk menyediakan energi listrik yang dibutuhkan olek perangkat keras. Diagram blok dari sistem power supply ditampilkan pada gambar 5

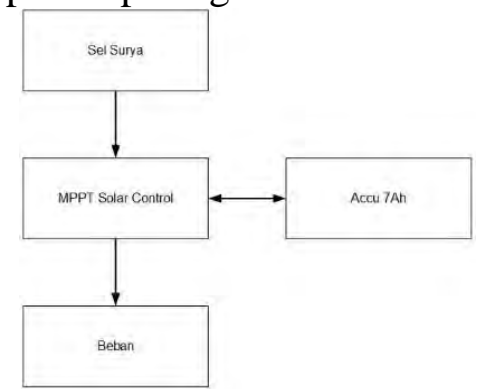

Gambar 5. Blok Diagram Power Sistem (Sumber: Rancangan dari sistem, 2018)

Sistem monitoring kualitas air danau dirancang sedemikian rupa dengan memanfaatkan teknologi IOT. Sehingga parameter-perameter yang menentukan kualitas air di danau yang diambil oleh sensor dapat dilihat secara on-line melalui web server oleh pengguna selama terhubung ke internet baik melalui PC ataupun smartphone. Web server akan menampilkan data yang diperoleh dari masing-masing modul sensor melalui web client sedangkan data base digunakan untuk menyimpan data-data dari modul sensor dari waktu kewaktu sehingga data dapat disimpan secara baik dan dapat dipanggil kapan pun dibutuhkan. Sistem manajemen data base diperlukan untuk memproses data, menampilkan data dalam bentuk grafik atau untuk menganalisa data kedepannya. Dalam sistem ini, data base dibuat dengan menggunakan MySQL, sedangkan untuk halaman web nya menggunakan php dan java scrip. Server web dalam sistem ini dirancang dengan beberapa fitur yang mampu menampilkan data dalam grafik dan tabel, dan mengekspor data dalam format Excel,

\section{HASIL DAN PEMBAHASAN}

Sistem monitoring kualitas air danau telah diujikan di telaga Ngebel Ponorogo Jawa Timur. Sistem menggunakan solar panel sebesar 20 watt sebagi sumber listrik. Buoy 
diletakkan 15 meter dari kerambahkerambah ikan milik masyarakat. Sistem mengirimkan paket data yang berasal dari pembacaan senso-sensor ke data base sebesar 16 byte. Pada halaman depan dari halaman web diperlihatkan beberapan parameter yang digunakan untuk mengetahui tingkat kualitas air di telaga Ngebel. Para meter tersebut terdiri dari kadar $\mathrm{PH}$, suhu air, tinggat kekeruhan dan jumlah kadar oksigen yang terlalut di telaga Ngebel. Nilainilai yang ditampilkan tersebut merupakan nilai dari hasil pembacaan yang paling terbaru. Pembacaan dilakukan dengan interval selama 10 menit.

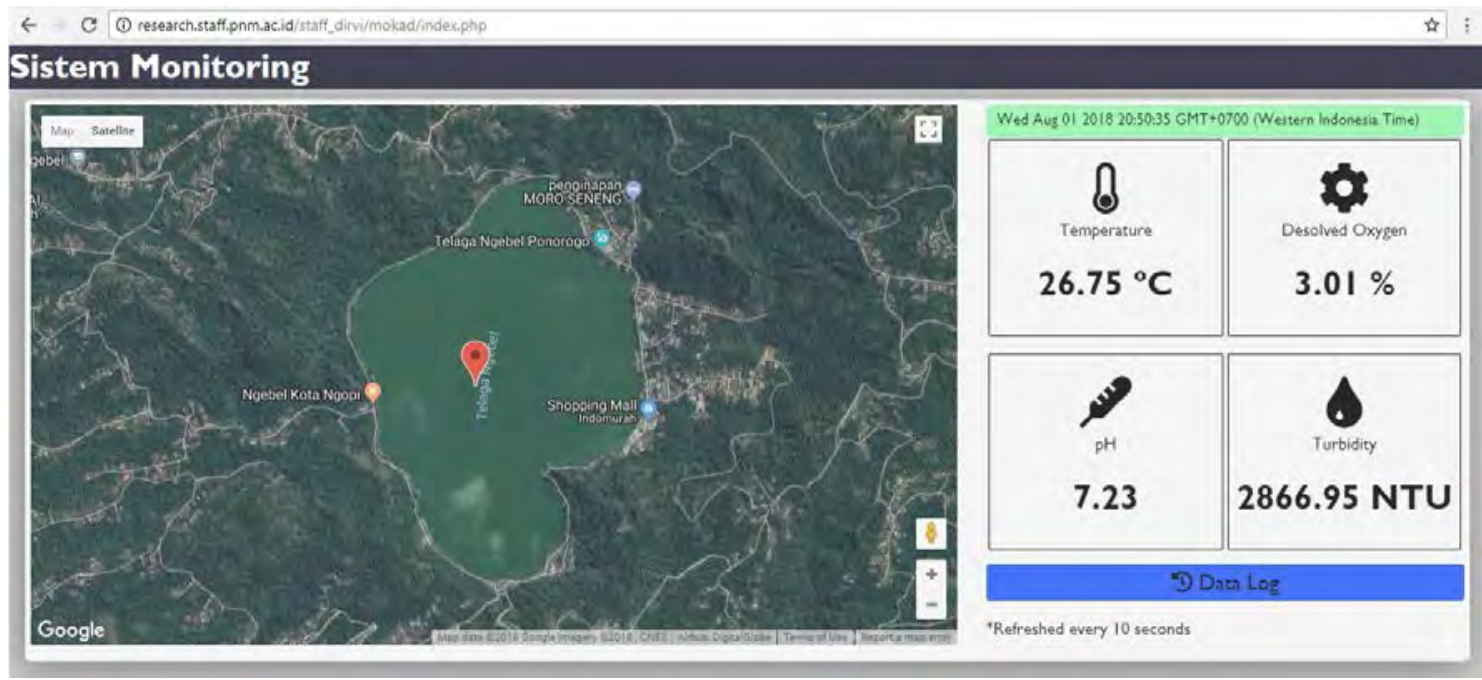

Gambar 6. Tampilan Depan Dari Halaman Depan Web Sistem Monitoring

(Sumber: Hasil Pembuatan Sistem, 2018)

Halaman web monitoring kualitas air danau bersifat open publik sehingga siapapun dapat mengaksesnya dan mengambil data-data yang dikumpulkan oleh sistem. Untuk menampilkan datadata dari sensor yang tersimpan di data base dapat dilakukan dengan memilih menu data log.

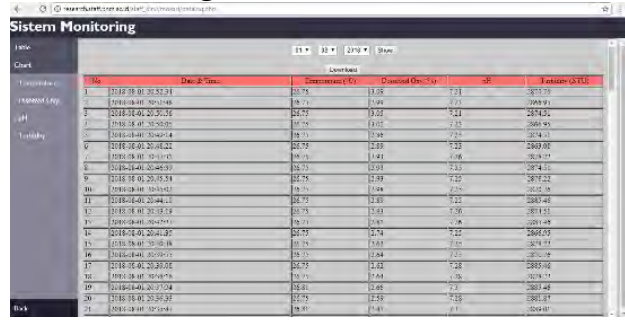

Gambar 7. Tampilan Dari Data Log Yang Disimpan Oleh Data Base

(Sumber: Hasil Pembuatan Sistem, 2018)

Pada menu data log publik dapat mengunduh data-data yang disimpan di data base berdasarkan tanggal yang mau dimulai untuk diamati. Data yang di unduh berbentuk table dengan format excel. Pada menu ini juga selain data disajikan dalam bentuk table, data juga dapat ditampilkan bentuk grafik. Grafik yang disajikan adalah grafik dari tiap masing-masing parameter terhadap waktu.

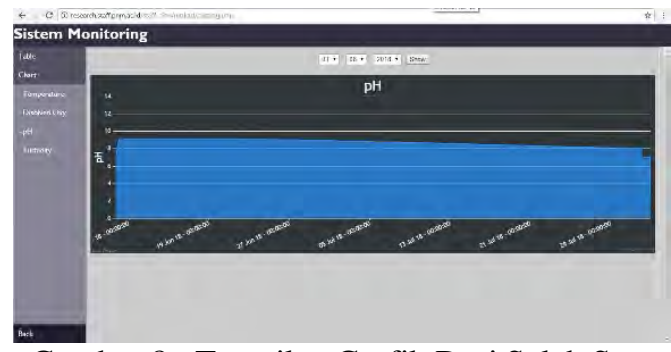

Gambar 8. Tampilan Grafik Dari Salah Satu Parameter Kualitas Air Danau (Sumber: Hasil Pembuatan Sistem, 2018) 


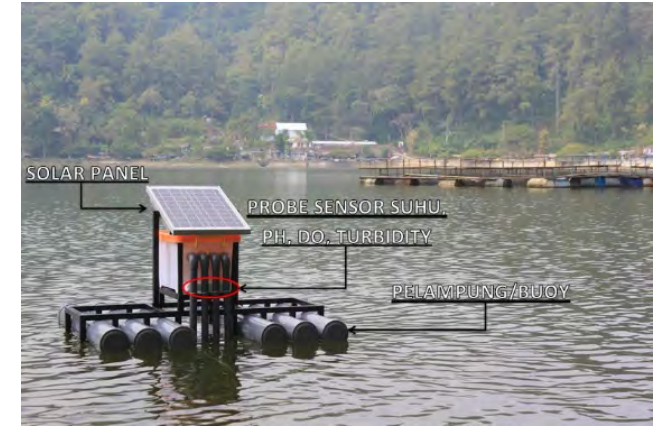

Gambar 9. Pengujian Sistem Monitoring Kualitas Air Danau (Sumber: Hasil Pembuatan Sistem, 2018)

\section{KESIMPULAN}

Pada tulisan ini sistem monitoring kualitas air danau berbasis IOT diujikan di telaga Ngebel, ponorogo Jawa Timur. Parameter kualitas air yang digunakan adalah kadar $\mathrm{PH}$, suhu, DO, dan turbidity. Data kualitas air danau dikumpulkan oleh modul sensor dengan besar data array 4 byte permodul sensor. Data dari sensor akan disimpan ke data logger sebelum dikirimkan ke web server dengan menggunakan komunikasi GPRS/GSM. Data logger mampu menyimpan data selama 41 jam pengamatan sensor. Ketika data di data logger berhasil dikirim maka sistem secara otomatis akan menghapus data yang ada di data logger. Seluruh data tersimpan di web server dan dapat diakses oleh masyarakat umum baik menggunakan computer maupun menggunakan smartphone. Sistem dirancang secara moduler sehingga sensor yang digunakan dapat dirubah, atau ditambah tanpa memerlukan perubahan rangkaian elektronika, cukup dengan plug $\mathrm{n}$ play. Sistem dapat dikembangkan menjadi pusat pemantauan kualitas air danau diseluruh Indonesia dengan cara memasang peratal ini dan mengintegrasikannya dalam satu web server. Hal ini akan sangat membantu pihak-pihak terkait seperti dinas prikanan untuk mencegah kejian kematian ikan secara masal di suatu danau atau telaga.

\section{DAFTAR PUSTAKA}

[1] A.Faustine, A. N. Mvuma, H. J. Mongi, M. C. Gabriel, A. J. Tenge, and S. B. Kucel. Wireless sensor networks for water quality monitoring and control within lake Victoria basin: prototype development. Wireless Sens. Net., 2014, 6: 281-290.

[2] A.Gaddam, M. Al-Hrooby, and W. F.Esmael. Designing a wireless sensors network for monitoring and predicting droughts. Proc. 8th. Int. Conf. Sens. Tech. Liverpool: 2014, pp. $210-215$.

[3] D. D. Ediriweera and I.W. Marshall. Monitoring water distribution systems: Understanding and managing sensor networks. Drink. Water Eng. Sci. 2010,3: 107-113.

[4] D. Hou, X. Song, G. Zhang, H. Zhang, and H. Loaiciga (2013). An early warning and control system for urban, drinking water quality protection: China's experience. Environ. Sci. Pollut. Res.2013,20:4496-4508.

[5] D. Sirisha, B. Venkateswaramma, M. Srikanth, and A. A. Babu. Wireless sensor-based remote controlled agriculture monitoring system using zigbee. SSRG Int. J. Elec. Com. Eng. 2015, 2 (4): 32 36.

[6] M. Shell. (2002) IEEEtran homepage on CTAN. [Online]. Available:

http://www.ctan.org/texarchive/ macros/latex/contrib/supported/IEE Etran/

[7] Y. Zhang, W. Yang, D. Han, and Y. -I. Kim. An integrated environment monitoring system for underground coal mines- wireless sensor network subsystem with multiparameter monitoring. Sens. 2014, 14: 13149-13170 